\title{
PERCEIVED QUALITY OF PERFORMANCE APPRAISAL SYSTEM AND ITS IMPACT ON JOB PERFORMANCE OF EMPLOYEES IN BANK OF CEYLON
}

\author{
T. Raveendran \\ Department of Human Resource Management \\ University of Jaffna, Sri Lanka. \\ rthanes67@gmail.com \\ T. Hameela \\ Bank of Ceylon, Jaffna \\ hameela7@gmail.com
}

\begin{abstract}
Performance appraisal is an integral part of any organization as it helps organizations ensuring employees are working hard to contribute to achieving the organization's mission and objectives. The objective of this study was to investigate the impact of performance appraisal system on job performance of employees of Bank of Ceylon in the Northern Province of Sri Lanka. The study was conducted with a sample of 173 employees who are working in Bank of Ceylon in the Northern Province of Sri Lanka. The study employed a survey method and questionnaires were used to collect data. The type of investigation was explanatory in nature and cross sectional according to time horizon. Pearson Product-Moment Correlation and regression analysis were used to test the hypotheses. There are many dimensions to measure the quality of performance appraisal system, however, the current study focused on four dimensions namely fairness of appraisal, appraisal satisfaction, relationship with peers and superiors and appraisal accuracy. The results of the study revealed that perceived quality of performance appraisal system has a positive impact on perceived degree of job performance. Multiple regression analysis revealed that fairness of appraisal and appraisal satisfaction have significant positive impact on job performance whereas relationship with peers and supervisors and appraisal accuracy do not significantly impact job performance. The finding of this study gives an insight to the banking sector to promote the performance of employees through quality of appraisal system.
\end{abstract}

Keywords: Bank of Ceylon; Job performance; Performance appraisal; Performance management 


\section{Background of the Study}

Performance appraisals are vital for the effective management of employee performance. Performance appraisal helps to develop employees as well as to improve organizational performance. Performance appraisal (PA) is concerned with determining how well employees are performing their tasks, communicating that information to the respective employees and establishing a plan for improving employee performance (Stone \& Reymond, 2002). PA is the personal activity by means of which the enterprise determines the extent to which the employee is performing the job effectively (Opatha, 2002). Performance Management is a dynamic process, while appraisals are part of performance management. Therefore, without appraisals performance management becomes difficult (Rao, 2004). Constructive and timely feedback during the PA period addressing the level of employee performance is an essential part of a successful performance management program. The assessment of employee performance helps managers to ensure that the strategic goals of the organization are achieved.

Performance evaluation is said to be a central part in performance management (Cardy, 2004). Rewarding performance is an important responsibility of management as employees' performance could be enhanced by establishing a clear link between the efforts and rewards (Thompson, 2001). According to Rao (2004), performance management with PA should lead to increased performance. However, PAs may lead to dissatisfaction and decreased performance if appraisals are not linked to rewards. Those who are not rewarded get demotivated. Rao (2004) mentioned that performance management system with appraisal element incorporated into them leads to improvement of performance, motivation and more competence among employees.

Little research has been carried out in Sri Lanka regarding Performance Appraisal System (PAS) in the banking sector (e.g. Hussain Ali, Raisal \& Mohammed Fasmy, 2014; Weerakkody \& Mahalakamge, 2013). The present research primarily intends to identify whether there is a relationship between perceived quality of PAS and the job performance of employees in Bank of Ceylon, Northern Province.

\section{Research Problem}

PAS can provide a complete and professional management process for assessing the performance of employees. Macky and Johnson (2000) mentioned that organizational performance could be improved by employees' performance. According to Employee 
Hand Book (2018) issued by Human Resources Division of Bank of Ceylon, the PAS aims at improving the bank's business results, and achieving corporate goals by enhancing the individual performance of employees. PA is done annually and it is expected that the appraisals should reach the HR Division in time. In Bank of Ceylon, PA is an important process to make decisions of confirmation, grading, promotions, annual increments, extension of service, training etc. Submission of PA reports in time to HR division is a joint responsibility of appraiser, appraisee and reviewers.

Bank of Ceylon spends much amount on training programmes to increase the job performance of the staff. Because of this reason identifying the factors influencing job performance is the most important part. There is a need to investigate the employees' perception of quality of PAS and its effect on their job performance in the bank.

This study addresses the following research question.

"Does perceived quality of performance appraisal system impact employee performance in Bank of Ceylon in the Northern Province of Sri Lanka?"

\section{Objective of the Study}

PA is PAS is an essential human resource activity for motivating employees, changing their attitude and modifying their behavior. It is also important for alignment of individuals' and organization's goals and promoting positive relationships between managers and employees. Improvement of employees' job performance is a key to competitive advantage. Thus, the objective of the present study is to identify the impact of perceived quality of PAS on job performance of employees in Bank of Ceylon in the Northern Province of Sri Lanka.

\section{Literature Review}

\subsection{Performance Appraisal}

PA is related with measuring how well employees do their tasks, communicate the information to employees and establish a plan for performance improvement (Stone \& Reymond, 2002). Hussain-Ali and Opatha (2008) mentioned that PA is concerned with measurement of employees' performance, influencing them, and developing their performance to meet the standards set for them in order to achieve the organizational goals. PA means the analysis of performance of employees and their ability for future development. It helps to find out who needs training, what type of training to be given and who can be promoted, demoted, or fired. Opatha (2002) 
mentioned that PA is the human resource activity by which the organizations determine the extent to which the employees are doing their job effectively.

There are two types of terms referring to PA; one type is referred to as the academic terms while other is referred to as practical terms. The terms performance appraisals, merit rating, employee evaluation and performance rating are considered as academic terms while the terms such as confidential report, increment report and company report are identified as practical terms used by industry practitioners (Opatha, 2002). Judge and Ferris (1993) mentioned that correct evaluation of employee performance has been regarded as a key to success of organizations. Performance management is a continuous process while PA is part of performance management and a periodic activity. A remarkable change in appraisal techniques since the mid-1900s has been a move toward more employee participation in the appraisal process. This includes selfappraisal, employees' input into evaluations, giving feedback and goal setting in consultation with employees. Appraisals focus on the process of establishing standards, setting individual goals, evaluating actual performance, and then determining whether the standards have been met. PA incorporates a wide range of criteria and appraisal methods to ensure the effectiveness of appraisal.

Armstrong (2006) mentioned that managing employee performance is a continuous process that involves clarifing mutual expectations, emphasizing the support of managers and focusing on the future. According to him, PA tend to be backward looking, concentrating on what went wrong, rather than focusing on future developmental aspects. The role of the performance management is to focus on what needs to be done by employees to achieve the purpose of the job, to meet challenges, to make use of their knowledge, skills and abilities, to develop their capabilities and to reach agreement on areas where performance needs to be improved (Armstrong, 2006).

\section{Job Performance}

Job performance is a measure of whether a person performs a job at expected quality. Job performance is an important criterion for organizations' success and growth. Campbell, Lee and IM (2016) describe job performance as an individual level variable and something an individual does. Employees' performance also is determined taking into account factors such as leadership skills, time management and other behaviours of individuals. Job performance reviews are often performed annually to determine 
pay raises, promotions, and even to make firing decision when the employee performance suffers. Many HR managers assess the employees' job performance on a regular basis in order to identify areas for improvement and for identifying training needs.

According to Bernardin (2008), job performance as a whole would be equal to the sum of performance of a major job function or tasks. In view of Bernardin (2008), there are six categories of outcomes by which the job performance could be assessed. These include quality of work, quantity of work, timelines, cost effectiveness, need for supervision and interpersonal relations. Even though all of these dimensions may not be applicable to every job function, a sub set of them will be relevant. The objective of PA is to help managers effectively manage employees and ultimately to enhance their productivity. PA serves that purpose by: (1) explaining employees how to increase their performance, (2) setting goals for them, and (3) assessing employees' performance and (4) take actions related to promotion, demotion, training, compensation, transfer, and termination.

\section{Empirical Evidence}

PA is an important tool for assessing employees' performance and implementing strategic initiatives for the employees' performance improvement (Lawler \& McDermott, 2003). However, studies suggest that there is dissatisfaction among employees regarding the PAS (Mercer, 2002; Roberson \& Stewart, 2006; Moullakis, 2005). For example, Morgan (2006) pointed out that the PA done in many organizations have not met the employees' expectations. Pichler (2019) suggests that organizations need to pay more attention to leader-member exchange quality, due process in appraisal, and giving opportunities for employees' voice in the appraisal discussion to promote the usefulness of appraisal.

Selvarajan and Cloninger (2009) have reported that good PAS results in improved employee performance and motivation. Khan, Hussain and Khan (2020) have reported that the dimensions of PAS are significantly related with job performance. According to them, the dimensions include goal setting and purpose, fairness of appraisal and appraisal methods. Goal is a standard for assessing employees' performance and committed employees are found to be high goal achievers and best performers within the organization (Teo \& Low, 2016). The PA process has significant effect on employee performance (Girmaa, Lodesso \& Sorsa, 2016). In this regard, 
weak performers and good performers within organizations could be identified. Prior studies have identified five important outcomes of effective PA: (1) using the appraisal results to promote employees' job performance, (2) Improving employee motivation, (3) minimizing employee turnover, (4) establishing a link between rewards and employee performance, and (5) ensuring fairness of appraisal (Rao, 2004; Selvarajan \& Cloninger, 2009).

Usually, PA results are utilized for developmental and administrative purposes in organizations. Feedback richness is one of the indicators that could influence the appraisal outcomes. Feedback richness is concerned with providing timely feedback by employers to employees regarding job performance (Kinicki, Prussia, Bin \& McKee-Ryan, 2004). Perceived accuracy of PAS is a vital feature to ascertain the satisfaction and motivation among employees regarding PA(Wood \& Marshall, 2008; Selvarajan \& Cloninger, 2009). Perceived fairness of appraisal measures effectiveness of appraisal outcomes (Youngcourt et al., 2007). Fairness of appraisal can be divided into three dimensions named distributive fairness, interactional fairness and procedural fairness (Colquitt et al., 2001). Distributive fairness refers to the extent to which outcomes of appraisal are distributed fairly (Smither \& London, 2009). Procedural fairness refers to the extent to which appraisal procedures are fair in getting outcomes of appraisal (Zapata-Phelan et al., 2009). Several studies have reported that fairness of PA is positively associated with employees' performance (for example, Selvarajan \& Cloninger, 2009; Abbas, 2014; Khan et al., 2018).

Appraisal satisfaction exemplifies the contentment of employees concerning the results of appraisal system. Levy and Williams (2004) suggest that examining employee satisfaction is essential as it shows reactions of employees regarding the appraisals. According to Abbas (2014), fairness of appraisal, appraisal accuracy and appraisal satisfaction have significant positive impact on employee performance whereas relations with peers and supervisors do not significantly impact employee performance. Organizations must use the PAS to enhance organizational performance and effectiveness (Rubin, 2011; Esu \& Inyang, 2009; Roberts, 2003). An important factor that determines success and suitability of PA is the reactions of ratees to the appraisal system (Carrol \& Schneier, 1982; Murphy \& Cleveland, 1991). Thus, acceptance of PAS depends on perception of its fairness (Kim \& Rubianity, 2011). Researchers suggest that the more employees perceive that the appraisal system is fair 
and reasonable, the more they report high level of satisfaction and trust regarding the appraisal system (Hedge \& Teachout, 2000; Mani, 2002; Gabris \& Ihrke, 2000). The proponents of PAS claim that managers can overcome the negative effects of appraisal by ensuring employee participation in the appraisal process (Murphy \& Cleveland, 1991; Roberts, 2003). Thus, managers have to focus on satisfaction of employees regarding the PAS.

The interpersonal relationship with raters and rates is also one of the important factors of successful appraisal system (Judge and Ferris, 1993; Reinke, 2003). Few studies have examined the effect of relationship between superiors (raters) and employees (ratees) on performance of employees, specially in the banking sector. In sum, we assume that managing employees' perception of fairness and accuracy of their PA, their relations with peers and superiors and the satisfaction about appraisal will foster more positive perceptions on their appraisal accuracy; in turn, it will lead to more job performance in the work.

On the basis of above mentioned literature, it can be assumed that quality of the performance evaluation practices are correlated with the perceived performance of employees. There are very few studies carried out in Sri Lanka in respect of employee performance evaluation. No prior empirical evidences are available on PAS and its relationship with organizational performance in Sri Lanka (Opatha, 2002). Thus, there is a gap in empirical knowledge available in Sri Lankan context, particularly in the banking sector. The present research primarily intends to identify the impact of perceived PAS on perceived job performance of employees of the Bank of Ceylon in the Northern Region. In this study, under the perceived quality of PAS, four dimensions namely fairness of appraisal, appraisal accuracy, relationship with peers $\&$ supervisors and performance appraisal satisfaction were considered.

\section{Methodology}

\subsection{Research Design}

The current study is explanatory in nature. On the other hand, this is a field survey which tried to understand the association between quality of PAS and degree of job performance of employees. Since data were collected within a particular period of time, this is a cross sectional study. For this study, the unit of analysis was individual employees who work in the Bank of Ceylon in the Northern Province. 


\subsection{Population and Sample}

Employees at Bank of Ceylon are categorized into three layers. They are staff assistants, executives and managers. The targeted employees in the current study include managers, executives and staff assistants. Population includes all three level staff of Bank of Ceylon in the Northern Province. The total population of employees working in Bank of Ceylon, Northern Province is 345 (as at January 2018) in 63 branches. This total population estimate is based on the employee database of the Human Resource Department of Bank of Ceylon. For the current study, $60 \%$ of the employees were selected as sample using random sampling method. 207 Questionnaires were issued to collect data and 173 were returned constituting a response rate of $83 \%$.

\subsection{Instruments}

Based on the extensive review of the literature and previous research conducted by authors, the survey questionnaire was developed. The survey questionnaire comprised three sections. The first section of the questionnaire comprised demographic questions. The second section consists of 14 Likert type questions which measure the perceived quality of PAS while third section contains 32 Likert type questions which measure perceived job performance. Levels of agreement for the statements were Strongly Disagree, Disagree, Neutral, Agree, and Strongly Agree and, values were given as 1, 2,3,4,5, respectively for each agreement mentioned above.

\subsection{Conceptualization}

Considering previous literature, researchers proposed a framework that illustrates the connection between perceived quality of PAS and perceived degree of job performance. Conceptual Framework of the study is shown in Figure 1.

\section{Perceived Quality of Performance}

\section{Appraisal System}

* Fairness of appraisal

* Appraisal accuracy

* Relations with peers \& supervisors

* Performance appraisal satisfaction

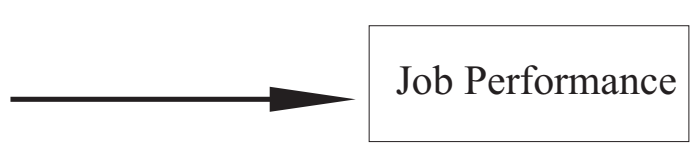

Figure1: Conceptual Framework

Journal of Business Studies, 7(2)

$-84-$

2020 


\subsection{Hypotheses}

Based on the review of literature, following hypotheses were formulated.

H1: There is a significant relationship between perceived quality of PAS and job performance.

$H 1_{a}:$ There is a significant relationship between fairness about appraisal and job performance

$H 1_{b}$ : There is a significant relationship between appraisal accuracy and job performance.

$H 1_{c}$ : There is a significant relationship between relationship with peers and supervisors andjob performance

$H 1_{d}$ : There is a significant relationship between performance appraisal satisfaction and job performance

H2: Perceived quality of PAS has a significant positive impact on job performance

$\mathrm{H}_{\mathrm{a}}$ : Fairness of appraisal has a significant positive impact on job performance

$H 2_{b}$ : Appraisal accuracy has a significant positive impact on job performance

$\mathrm{H}_{c}$ : Relationship with peers and supervisors has a significant positive impact onjob performance

$H 2_{d}$ : Performance appraisal satisfaction has a significant positive impact on job performance

\section{Data Analysis}

In this study, the data were analyzed using SPSS 20.0 and regression analysis was performed to identify the impact of PAS on employee performance. First the missing data were addresses. As there was less number of cases with missing data, the mid points were entered in the data set. In case of linearity, the scatterplot of each pair of dependent and independent variables showed a linear pattern. Then, normality was tested using skewness and kurtosis values of each variable. The values between +2 and -2 are acceptable (George \& Mallery, 2010). The values of skewness and kurtosis are within the acceptable range and thus normality exists in the data. The preliminary analysis of data shows that the data are suitable for analysis.

Journal of Business Studies, 7(2)

$-85-$

2020 
Table 1: Sample Profile

\begin{tabular}{|l|c|c|c|}
\hline & Frequency & Percent & $\begin{array}{c}\text { Cumulative } \\
\text { Percent }\end{array}$ \\
\hline Age & - & - & - \\
\hline Below 25 & 126 & 72.8 & 72.8 \\
\hline $25-34$ & 36 & 20.8 & 93.6 \\
\hline $35-44$ & 6 & 3.5 & 97.1 \\
\hline $45-54$ & 5 & 2.9 & 100.0 \\
\hline Above 55 & 84 & 48.6 & 48.6 \\
\hline Gender & 89 & 51.4 & 100.0 \\
\hline Male & & & \\
\hline Female & 52 & 30.1 & 30.1 \\
\hline Marital status & 121 & 69.9 & 100.0 \\
\hline Single & & & 76.9 \\
\hline Married & 40 & 50.3 & 50.3 \\
\hline Job category & & 26.6 & 100.00 \\
\hline Staff Assistant & & & \\
\hline Executive & & & \\
\hline Manager & & & \\
\hline
\end{tabular}

Source: Survey Data

As can be seen in Table 1, majority of the participants were in the age group of 25-34 $(72.8 \%)$ and majority were females (51.4\%). In case of marital status, $69.9 \%$ were married. Half of the participants were staff assistants and the remaining were executives $(26.6 \%)$ and managers $(23.1 \%)$.

\subsection{Reliability}

The reliability of the scales was measured using Cronbach's alpha. The alpha values for all constructs exceeded the minimum requirement of 0.7 (Nunnally, 1978). As the reliability was confirmed data analysis was proceeded. 


\subsection{Correlation Analysis}

Correlation analysis was employed to investigate the relationship between perceived quality of PAS and perceived job performance. Pearson Product-Moment correlation technique was used for this purpose.

Table 2: Correlation between Quality of PAS and Job Performance

\begin{tabular}{|l|c|}
\hline Performance Appraisal System (PAS) & Job Performance \\
\hline Fairness of Appraisal & $.354^{* *}$ \\
\hline Appraisal Accuracy & $.282^{* *}$ \\
\hline Relations with Peers and Supervisors & $.333^{* *}$ \\
\hline Performance Appraisal Satisfaction & $.343^{* *}$ \\
\hline Performance Appraisal System & $.391 * *$ \\
\hline
\end{tabular}

**. Correlation is significant at the 0.01 level (2-tailed).

Source: Survey Data

According to the results, correlation between perceived quality of PAS and perceived degree of job performance is 0.391 and the relationship is significant at 0.01 level. It indicates that there is significant positive relationship between perceived quality of PAS and perceived degree of job performance. Therefore, H1: There is a significant relationship between perceived quality of PAS and job performance is supported.

The correlation results reported in Table 2 show that there is significant positive relationship between fairness of appraisal and employee performance $(r=.354, p=$ $.000)$, appraisal accuracy and employee performance $(\mathrm{r}=.282, \mathrm{p}=.000)$, relationship with peers and supervisors and employee performance $(r=.333, p=.000)$ and performance appraisal satisfaction and employee performance $(r=.343, \mathrm{p}=.000)$. Based on the results, the hypotheses $\mathrm{H}_{\mathrm{a}}, \mathrm{H}_{\mathrm{b}}, \mathrm{H}_{\mathrm{c}}$ and $\mathrm{H} 1_{\mathrm{d}}$ are supported.

\section{Regression Analysis}

Regression analysis was used to measure the impact of performance appraisal system on employee performance. The results are shown in Table 3 
Table 3: Results of Regression Analysis for the Impact of PAS on Job Performance

\begin{tabular}{|c|c|c|c|c|c|c|c|}
\hline \multirow[t]{2}{*}{ Model } & \multicolumn{2}{|c|}{$\begin{array}{l}\text { Unstandardized } \\
\text { Coefficients }\end{array}$} & \multirow{2}{*}{$\begin{array}{l}\begin{array}{l}\text { Standardized } \\
\text { Coefficients }\end{array} \\
\text { Beta }\end{array}$} & \multirow[b]{2}{*}{$\mathrm{T}$} & \multirow[b]{2}{*}{ Sig. } & \multirow[b]{2}{*}{ F } & \multirow[b]{2}{*}{ Sig } \\
\hline & B & Std.Error & & & & & \\
\hline (Constant) & 3.041 & .127 & & 23.929 & .000 & \multirow[b]{2}{*}{30.885} & \multirow[b]{2}{*}{.000} \\
\hline $\begin{array}{l}\text { Performance } \\
\text { Appraisal system }\end{array}$ & .059 & .011 & .391 & 5.557 & .000 & & \\
\hline $\mathbf{R}=.391$ & square & .153 & & & & & \\
\hline
\end{tabular}

\section{Source: Survey Data}

The Table 3 shows that PAS has a significant positive impact on job performance ( $\beta=$ $0.059, \mathrm{P}<0.01)$. Based on the results, the Hypothesis 2 : Perceived quality of PAS has a significant positive impact on job performance is supported. As per the results reported in Table 3, 15.3\% of the variation in perceived job performance is accounted for perceived quality of PAS.

Table 4: Multiple Regression Analysis

\begin{tabular}{|c|c|c|c|c|c|c|c|}
\hline \multicolumn{6}{|l|}{ Coefficients $^{\mathrm{a}}$} & \multirow[b]{4}{*}{$\mathrm{F}$} & \multirow[b]{4}{*}{ Sig. } \\
\hline \multirow[t]{3}{*}{ Model } & \multirow{2}{*}{\multicolumn{2}{|c|}{$\begin{array}{c}\text { Unstandardized } \\
\text { Coefficients }\end{array}$}} & \multirow{3}{*}{$\begin{array}{c}\begin{array}{c}\text { Standardized } \\
\text { Coefficients }\end{array} \\
\text { Beta }\end{array}$} & \multirow[b]{3}{*}{$\mathrm{T}$} & \multirow[b]{3}{*}{ Sig. } & & \\
\hline & & & & & & & \\
\hline & B & Std. Error & & & & & \\
\hline (Constant) & 2.968 & .135 & & 21.968 & .000 & \multirow{5}{*}{8.408} & \multirow{5}{*}{$.000^{\mathrm{b}}$} \\
\hline Fairness of appraisal & .101 & .048 & .213 & 2.091 & .038 & & \\
\hline Appraisal accuracy & -.017 & .041 & -.044 & -.417 & .677 & & \\
\hline $\begin{array}{l}1 \text { Relations with peers } \\
\text { and supervisors }\end{array}$ & .053 & .045 & .117 & 1.168 & .244 & & \\
\hline $\begin{array}{l}\text { Performance appraisal } \\
\text { satisfaction }\end{array}$ & .089 & .044 & .189 & 2.010 & .046 & & \\
\hline \multicolumn{6}{|c|}{$\mathrm{R}=.408^{\mathrm{a}}, \quad \mathrm{R}$ square $=.167$} & & \\
\hline \multicolumn{6}{|c|}{ a. Dependent Variable: Job Performance } & & \\
\hline
\end{tabular}

Source: Survey Data

Journal of Business Studies, 7(2)

$-88-$

2020 
The multiple regression analysis results reported in Table 4 show that fairness of appraisal has significant positive impact on job performance $(\beta=0.101, \mathrm{P}<0.05)$. Impact of appraisal accuracy on job performance is not significant $(\mathrm{P}>0.05)$. Impact of relationship with peers and supervisors on job performance also is not significant $(\mathrm{P}$ $>0.05)$. Performance appraisal satisfaction has a significant positive impact on job performance $(\beta=0.089, \mathrm{P}<0.05)$. Based on the results, the hypotheses $\mathrm{H} 2_{\mathrm{a}}$ and $\mathrm{H} 2_{\mathrm{d}}$ are supported whereas $\mathrm{H} 2_{\mathrm{b}}$ and $\mathrm{H} 2_{\mathrm{c}}$ are not supported. According to the multiple regression analysis, the $\mathrm{R}$ square is 0.167 . It means that $16.7 \%$ of the variation in employees' job performance is explained by the dimensions of perceived quality of PAS.

\section{Discussion}

The current study was aimed at identifying the impact of perceived quality of PAS and perceived job performance of employees in the bank of Ceylon, Northern Province. The study has revealed that perceived quality of PAS has a significant impact on job performance. The finding of the study is consistent with prior studies (for example, Selvarajan \& Cloninger, 2009; Girmaa, Lodesso, \& Sorsa, 2016).

In case of dimensions of quality of PAS, the fairness in appraisal has a significant impact on perceived job performance. The finding is in line with the previous studies (e.g. Roberson \& Stewart, 2006; Abbas, 2014). Fair performance evaluation and proper training motivates employees that results in improved performance and achieve organizational competitiveness (Shaharyar et al., 2014). However, in the current study, the impact of appraisal accuracy on job performance is not significant. The finding is not concurrent with the results of Abbas (2014). The inconsistent finding could be due to the context and sector concerned. The study of Abbas (2014) was conducted in Pakistani organizations which were from non-banking sector and thus the results of the currents study do not comply with it. The effect of relationship with peers and supervisors also is not significant and the result is consistent with the finding of Abbas (2014). At the same time, appraisal satisfaction has a significant positive impact on job performance and the results are in line with the previous studies (e.g. Levy \& Williams, 2004; Abbas, 2014). 


\section{Recommendations}

According to the findings of the present study, the researcher found that quality of PAS (overall) has a significant impact on the degree of job performance. Based on the study results, the following recommendations are given.

- It is necessary to develop and communicate relevant goals for the year at the beginning of the year. Evaluators need to pay much more consideration regarding the goals to be achieved through their subordinates in order to promote fairness in appraisal.

- In the Bank of Ceylon, the employee performance is evaluated by the employees (self-appraisal) as well as their superiors. Therefore, appraisers and appraisees should be trained properly about how to carry out a proper evaluation without any biases to promote accuracy in appraisal results about job performance of the subordinates.

- According to respondent's comments, PA is used only for earning marks for promotions and increments and it is very rarely used as a tool for improving the job performance. Therefore, performance appraisal system and criteria for appraisal should be revised time to time and employees should participate in the process to promote appraisal satisfaction among employees.

\section{Limitations and Suggestions for Future Studies}

This study is rather explanatory in nature and cross sectional. In order to study the relationship between the variables, it is necessary to do longitudinal study to measure the perceived quality of appraisal system and job performance of employees. This study was limited to Bank of Ceylon, Northern Province branches and therefore, future research could be extended to other banks and to other regions of Sri Lanka with a larger sample size. In addition, the relationship among the variables could be compared between different banks by future researchers. Further, it is recommended that future studies may examine the relationship between PAS and job performance across different job categories. There are many dimensions to measure the quality of PAS, however, the current study focused on four dimensions namely fairness of appraisal, appraisal satisfaction, relationship with peers and superiors and appraisal accuracy. Therefore, the other dimensions such as appraisal feedback, rewarding for performance and performance improvement plan should be covered by the future researchers.

Journal of Business Studies, 7(2)

$-90-$

2020 


\section{References:}

Abbas, M. Z. (2014). Effectiveness of performance appraisal on performance of employees. JOSR Journal of Business and Management, 173-178.

Abbas, M. Z. (2014). Effectiveness of performance appraisal on performance of employees. Journal of Business and Management, 16(6), 173-178.

Amstrong, M. (2006). A Hand Book of Human Resource Management Practice (10th ed.). Nodia: Gopons Papers Ltd.

Bernardin, H. (2008). Human Resource Management: An Experimental Approach (4th ed.). New Delhi: Tata McGrew-Hill Publishing Company Ltd.

Campbell, J. W., Lee, H., \& Im, T. (2016). At the expense of others: Altruistic helping behaviour, performance management and transformational leadership. Public Management Review, 18(6), 795-818.

Cardy, R. L. (2004). Performance management: Concepts, skills, and exercises. Armonk, NY: M. E. Sharpe.

Carroll, S. J., Schneier, C. E. (1982). Performance appraisal and review systems: The identification of measurement, and development of performance in organizations. Glenview, IL: Scott Foresman.

Colquitt J.A., Conlon D.E., Wesson M.J., Porter H., \& Ng, K.Y. (2001). Justice at the Millennium: A Meta-Analytic Review of 25 Years of Organizational Justice Research. Journal of Applied Psychology, 3, 425-445.

Employee Handbook (2018), Human Resource Division, Bank of Ceylon, Sri Lanka

Esu, B. B., Inyang, B. J. (2009). A case for performance management in the public sector in Nigeria. International Journal of Business and Management, 4(4), 98105.

Gabris, G. T., Ihrke, D. M. (2000). Improving employee acceptance toward performance appraisal and merit pay systems: The role of leadership credibility. Review of Public Personnel Administration, 20, 41-53. 
Girmaa, T., Lodesso, S.L. \& Sorsa, G. (2016). The Effect of Performance Appraisal on Employee Performance: A Survey on Administrative Staff of Hawassa Univesity. Journal of Business and Management 18(3), 36-44

Hedge, J. W., Teachout, M. S. (2000). Exploring the concept of acceptability as a criterion for evaluating performance measures. Group \& Organization Management, 25, 22-44.

Henderson, R.I. (1984). Performance Appraisal. (2nd ed.), Reston, VA: Reston Publishing Co

Hussain Ali, M. A. M., \& Opatha, H. H. D. N. P. (2008). Performance appraisal system and business performance: An empirical study in Sri Lankan Apparel Industry. Sri Lankan Journal of Human Resource Management, 5 (1), 23-37.

Hussain Ali, M. A. M., Raisal, I., \& Mohammed Fasmy, N. (2014). Impact of effective performance appraisal system (PAS) on employees' commitment in the selected branches of State Banks of Sri Lanka.

Judge, T. A., Ferris, G. R. (1993). Social context of performance evaluation decisions. Academy of Management Journal, 36, 80-105.

Khan, M. A., Hussain, A., \& Khan, M. H. (2020). The Moderating Effect of Employee Satisfaction on the Relationship of Goal-Setting and Purposes, Fairness and Rating Scale Format with Employee Job Performance. Journal of Business and Social Review in Emerging Economies, 6(1), 309-320.

Khan, M.A., Ismail, F.B., Yusoff, R.M., Hussain,A., \& Yunus, F. B. M. (2018). The Impact of Performance Appraisal on Employee Job Performance in Public Sector Universities of Khyber Pakhtunkhwa, Pakistan. International Journal of Engineering \& Technology, 7(3.25), 544-548.

Kim, S. E., Rubianty, D. (2011). Perceived fairness of performance appraisals in the federal government: Does it matter? Review of Public Personnel Administration, 31,329-348.

Kinicki, A.J., Prussia, G.E., Bin, W., \& McKee-Ryan, F.M. (2004. A Covariance Structure Analysis of Employees' Response to Performance Feedback. Journal of Applied Psychology, 89(6), 1057-1069. 
Lawler E.E., \& McDermott M. (2003). Current Performance Management Practices: Examining the Varying Impacts. World at Work Journal, 12(2), 49-60

Levy P.E., \& Williams J.R. (2004). The Social Context of Performance Appraisal: A Review and Framework for the Future. Journal of Management, 30(6), 881-905.

Macky, K. \& Johnson, G. (2000). The strategic Management of Human Resources in New Zealand. Auckland, New Zealand: Irwin/McGraw-Hill

Mani, B. G. (2002). Performance appraisal systems, productivity, and motivation: A case study. Public Personnel Management, 31, 141-159.

Mercer. (2002). Effective Performance Management Practices. New York: Mercer Human Resource Consulting.

Morgan, R. (2006). Making the Most of Performance Management Systems. Compensation and Benefits Review, 38, 22-27.

Moullakis J. (2005). One in Five Workers “Actively Disengaged”. The Australian Financial Review, 10

Murphy, K., Cleveland, J. (1991). Performance appraisal: An organizational perspective. Boston, MA: Allyn \& Bacon.

Nunnally, J. C. (1978). Psychometric theory. New York: McGraw-Hill.

Opatha, H.H.D.N.P. (2002). Performance Evaluation of Human Resource (2 ed.). Colombo: Institute of Management Studies and Science.

Pichler, S. (2019). Performance appraisal reactions: A review and research agenda. Feedback at Work, 75-96.

Rao T.V. (2004). Performance Management and Appraisal Systems: HR Tools for Global competitiveness. New Delhi: Response Books (A division of Sage Publications).

Reinke, S. J. (2003). Does the form really matter? Leadership, trust, and acceptance of the performance appraisal process. Review of Public Personnel Administration, 23, 23-37.

Journal of Business Studies, 7(2)

$-93-$

2020 
Roberson Q.M. \& Stewart M.M. (2006). Understanding the Motivational Effects of Procedural and Informational Justice in Feedback Processes. British Journal of Psychology, 97(3), 281-298.

Roberts, G. E. (2003). Employee performance appraisal system participation: A technique that works. Public Personnel Management, 32, 89-98.

Rubin, E. V. (2011). Appraising performance appraisal systems in the federal government: A literature review, preliminary findings, and prospects for future research. Paper presented at the Public Management Research Conference, Syracuse University, NY.

Selvarajan R. \& Cloninger P.A. (2008). The Importance of Accurate Performance Appraisals for Creating Ethical Organizations. Journal of Applied Business Research, 24(3), 39-44.

Selvarajan T.T. \& Cloninger, P.A. (2009). The Influence of Job Performance Outcomes on Ethical Assessments. Personnel Review, 38(4), 398-412.

Shaharyar, M., Baloch, M. A., Tariq, M. A., Mushtaq, S., \& Mushtaq, A. (2014). Impact of performance appraisal on employee performance. Journal of Resources Development and Management-An Open Access International Journal, 3.

Shahzad, K., Bashir, S., \& Ramay, M. I. (2008). Impact of Practice on Perceived Performance Perceived Performance of University Teachers in Pakisthan. International Reveiws of Business Research Papers, 4, 302-315.

Smither, J.W. \& London, M. (2009). Best Practices in Performance Management. In Performance Management: Putting Research into Action, (eds). J.W. Smither and M. London, San Francisco, CA: Jossey-Bass

Stone, \& Raymand, J. (2002). Human Resource Management (4 ed.). Singapore: Jhon Willy \& Sons Austraila Ltd.

Teo, T. C., \& Low, K. C. P. (2016). The impact of goal setting on employee effectiveness to improve organisation effectiveness: Empirical study of a hightech company in Singapore. Journal of Business \& Economic Policy, 3(1), 1-16. 
Weerakkody, W. A. S., \& Mahalakamge, W. G. S. (2013). The Relationship between Performance Appraisal Satisfaction and Employee Outcomes: With Special Reference of Bank of Ceylon Head Office. Kelaniya Journal of Human Resource Management, 8(2).

Wood, R.E. \& Marshall, V. (2008). Accuracy and Effectiveness in Appraisal Outcomes: The Influence of Self-Efficacy, Personal Factors and Organisational Variables. Human Resource Management Journal, 18(3), 295-313

Youngcourt, S.S., Leiva, P.I., \& Jones, R.G. (2007). Perceived Purposes of Performance Appraisal: Correlates of Individualand Position-Focused Purposes on Attitudinal Outcomes. Human Resource Development Quarterly, 18(3), 315343.

Zapata-Phelan, C., Colquitt, J., Scott, B., \& Livingston, B. (2009). Procedural Justice, Interactional Justice, and Task Performance: The Mediating Role of Intrinsic Motivation. Organizational Behavior and Human Decision Processes, 108(1), 93-105 